\title{
STRATEGI GURU DALAM MENINGKATKAN MINAT BELAJAR SISWA PADA MATA PELAJARAN PENDIDIKAN AGAMA ISLAM DI SEKOLAH DASAR NEGERI 147 PALEMBANG
}

\author{
Syamsiyah Nasution ${ }^{1}$ \\ Barorohriski@gmail.com
}

\begin{abstract}
ABSTRAK
Tujuan penelitian Untuk mengetahui minat belajar siswa pada mata pelajaran Pendidikan Agama Islam dan strategi guru dalam proses pembelajaran untuk peningkatan minat belajar siswa pada mata pelajaran Pendidikan Agama Islam di SDN 147 Palembang. Jenis penelitian ini adalah penelitian kualitatif, yaitu suatu penelitian yang ditujukan untuk mendeskripsikan dan mengalisis fenomena dan peristiwa .Teknik pengumpulan data melalui wawancara, observasi, penyebaran angket dan dokumentasi. Data yang digunakan dalam penelitian ini adalah data primer dan data sekunder. Data primer adalah data yang diperoleh peneliti dari hasil observasi terhadap guru PAI dalam proses pembelajaran di kelas; untuk mengamati apa saja strategi guru dalam proses pembelajaran, kemudian hasil wawancara dengan guru PAI dan kepala sekolah; untuk mengetahui minat belajar siswa pada mata pelajaran PAI dan pengembangan strategi guru untuk peningkatan minat belajar siswa pada mata pelajaran PAI, lalu hasil penyebaran angket terhadap siswa; untuk menjaring data tentang minat belajar siswa pada mata pelajaran PAI dan strategi guru dalam proses pembelajaran untuk peningkatan minatbelajar siswa pada mata pelajaran PAI, sedangkan data sekunder adalah data dokumentasi yang terdiri dari struktur organisasi, profil sekolah, keadaan guru dan pegawai, keadaan siswa, dan keadaan sarana dan prasarana yang dimiliki sekolah.Adapun teknik pengelolaan data melalui empat tahap yakni; pengumpulan data, mengklasifikasi data, menjelaskan data, lalu menarik kesimpulan. Berdasarkan hasil analisis data dapat diketahui bahwa, 1) Minat belajar siswa kelas V pada mata pelajaran PAI tergolong baik. Hal ini disebabkan karena dua faktor yang telah mendukung minat belajarnya, yaitu dari faktor perhatian dan insentif.hal ini terbukti dari kehadirannya di kelas, keaktifannya dalam proses pembelajaran, dan kepatuhannya terhadap tugas yang diberikan guru baik berupa hafalan maupun tulisan. 2) Pengembangan strategi pembelajaran yang digunakan guru untuk peningkatan minat belajar siswa pada mata pelajaran Pendidikan Agama Islam dikelas V SD Negeri 147 Palembang sudah cukup baik, hal ini dapat dilihat dari strategi memberi perhatian sebesar $80,90 \%$, sedangkan strategi memberi insentif katagori sedang atau cukup yaitu sebesar 76,19\%.
\end{abstract}

Kata Kunci: Strategi Guru dalam;Proses pembelajaran, peningkatan;Minat Belajar Siswa, Mata Pelajaran PAI.

\footnotetext{
${ }^{1}$ Dosen IAIN Padangsidimpuan
} 


\begin{abstract}
The purpose of research To determine student interest in the subject of Islamic education and strategies of teachers in the learning process to increase student interest in the subject of Islamic Education in SDN 147 Palembang. The research is a qualitative research, a study that aimed to describe and mengalisis phenomena and events. Teknik data collection through interviews, observation, questionnaire and documentation. The data used in this study are primary data and secondary data. Primary data is data obtained by researchers from the observation of the PAI teacher in the learning process in the classroom; to observe what strategies the teacher in the learning process, then the results of interviews with PAI teachers and principals; to determine student interest in the subject of PAI and development strategies for the improvement of teacher student interest in the subject of PAI, and the results of questionnaire to students; to gather data on student interest in the subject of PAI and strategies of teachers in thelearning process to increase studentinterest in the subject of PAI, while secondary data is data documentation consisting of the organizational structure, the profile of the school, teachers and state employees, the state of the student, and state-owned infrastructure sekolah.Adapun data management techniques through four stages namely; collecting data, classifying the data, explain the data, and draw conclusions. Based on the analysis of data it can be seen that, 1) Interest in learning fifth grade students on subjects PAI quite good. This is due to two factors that have supported the interests of learning, which is of concern and insentif.hal factor is evident from the presence in class, active involvement in the learning process, and compliance with the assignment of teachers either memorized or written. 2) Development of learning strategies used by teachers to increase student interest in the subject of Islamic Education in class $V$ Elementary School 147 Palembang is good enough, it can be seen from the strategy gives attention of $80.90 \%$, while the strategy is being or incentivize category enough is equal to $76.19 \%$.
\end{abstract}

Keywords: Master Strategies in;Learning, an increase in interest;Student, Subjects Islamic Education.

\title{
A. PENDAHULUAN
}

Undang-Undang Republik Indonesia Nomor 20 Tahun 2003tetang Sistem Pendidikan Nasional menyatakan bahwa jabatan guru sebagai pendidik merupakan jabatan profesional. Dengan demikian profesionalisme guru dituntut terus berkembang sesuai dengan perkembangan zaman, perkembangan ilmu pengetahuan dan teknologi, serta kebutuhan masyarakat. Oleh karena itu,sudah menjadi keharusan bagi guru untuk terus berinovasi menemukan strategi yang tepat dalam proses pembelajaran sehingga perkembangan tersebut lebih bermakna, baik bagi guru maupun siswa. Guru yang profesional adalah guru yang memiliki keahlian sebagai guru, 
tidak hanya memenuhi berbagai kualifikasi, baik kepribadian, kemampuan mengajar, penguasaan spesialisasi dalam bidang studi tertentu, tetapi juga harus memiliki kemampuan dalam rangka pengembangan kurikulum sesuai fungsi manajemen. ${ }^{2}$

Dalam upaya pencapaian tujuan kurikulum tersebut, guru merupakan komponen pengajaran yang memegang peranan penting karena salah satu tugas pokoknya adalah mengajar. Mengajar merupakan tugas mengorganisasi dan mengatur jalannya proses belajar mengajar. Oleh karena itu, setiap guru perlu membuat persiapan pengajaran atau satuan pelajaran, sehingga dengandemikian ia dapat menggunakan dan mengatur alokasi waktu yang tersedia secara efektif dan efesien. Perencanaan pengajaran yang dipersiapkan oleh guru pada dasarnya berfungsi antara lain: (1) menentukan arah kegiatan pengajaran/pembelajaran,(2) memberi isi dan makna tujuan, (3) menentukan cara bagaimana menggapai tujuan yang ditetapkan, dan(4) mengukur seberapa jauh tujuan itutelah tercapai dan tindakan apa yang harus dilakukan apabila tujuan belum tercapai. ${ }^{3}$

Keberhasilan pendidikan tidak luput dari proses pembelajaran. Diantaranya adalah strategi pembelajaran yang di dalamnya terdapat metode dan teknik. Pemilihan strategi pembelajaran yang sesuai materi, keadaan dan kemampuan siswa akan membuat proses pembelajaran lebih optimal. Strategi pembelajaran merupakan komponen yang penting dalam setiap kegiatan pembelajaran. Oleh karena itu, dengan penggunaan strategi yang tepat dalam pembelajaran, akan tercapai tujuan secara maksimal. Peranan strategi pembelajaran pada kegiatan pembelajaran yang optimal akan mengefektifkan proses tersebut, semakin efektifnya proses, semakin tinggi pula hasil yang akan dicapai. Adanya kurikulum yang disusun dengan baik belum tentu akan berpengaruh banyak pada prestosi peserta didik, jika tidak didukung oleh strategi pembelajaran yang sesuai. ${ }^{4}$ Belajar yang tidak menggairahkan bagi peserta didik biasanya lebih banyak mendatangkan kegiatan pembelajaran yang kurang efektif. Tentu saja hal ini menjadi kendala bagi tercapainya tujuan pembelajaran. ${ }^{5}$ Sebagai seorang penyampai pesan atau materi pelajaran, guru dituntut untuk senantiasa kreatif dan inovatif dalam proses pembelajaran agar dapat membangkitkan minat belajar siswa. Berhasil atau tidaknya kurikulum pendidikan yang telahdirencanakan/ditetapkan kuncinyaadalah terletak pada proses belajar

\footnotetext{
${ }^{2}$ Hamalik, Oemar. 2010. Pendidikan Guru: Berdasarkan Pendekatan Kompetensi. Bumi Aksara,Jakarta. ${ }^{3}$ Nurdin, Muslim, dkk. 2002. Moral dan Kognisi Islam. Alfabeta,Bandung.

${ }^{4}$ Zamroni. 2010. Pendidikan Masa Depan. Bigraf Publising,Yogyakarta.

${ }^{5}$ Djamarah, Syaiful Bahri dan Aswan Zain. 2010. Strategi BelajarMengajar. Rineka Cipta, Jakarta.
} 
mengajar sebagai ujung tombak dalam mencapai sasaran. ${ }^{6}$ Proses belajar akan berjalan dengan lancar apabila ada minat. Oleh karena itu, guru harus mampu mengakitkan minat siswa pada saat berlangsungnya proses pembelajaran.

Berdasarkan hasil observasi awal peneliti ketika proses pembelajaran berlangsung di SDN 147 Palembang, masih terdapat siswa yang kurangberminat mengikuti pembelajaran PAI, seperti ada siswa minta izin mau kekamar mandi, tapi ternyata ia berjalan berkeliling di belakang sekolah; Selain itu, ada pula yang ngobrol dengan teman sebangku (Observasi di kelas Vd SD Negeri 147 Palembang). Gejala-gejala tersebut menunjukkan bahwa siswa kelas V memiliki minat belajar yang rendah saat mengikuti pembelajaran PAI. Menurut peneliti, gejala-gejala tersebut di atas merupakan pengaruh dari pengelolaan kelas dan pengembangan strategi pembelajaran yang belum optimal, karena guru merupakan sentral dan sumber kegiatan belajar mengajar, seperti pada pengelolaan kelas, penggunaan strategi pembelajaran, dan pemahaman materi merupakan hal yang sangat penting bagi guru untuk direncanakan dan dikembangkan secara optimal.

Siswa yang tidak ada minat belajar kemungkinan tidak sesuai dengan bakatnya, kebutuhan, kecakapan, tipe-tipe khusus siswa. Oleh karena itu, guru hendaknya mengenal siswanya baik dalam hal bakat, kebutuhan, kecakapan, dan tipe-tipe khusus siswa, karena dengan mengenal siswa akan memudahkan guru dalam menstransfer ilmu pengetahuan maupun bimbingan terhadap siswa tersebut Jadi, terdapat siswa kurang minat belajar, hendaknya guru menggunakan stategi yang tepat guna meningkatkan minat belajar siswa tersebut.Berdasarkan uraian latar belakang masalah tersebut, maka penulis memandang penting melakukan penelitian tentang "Strategi Guru dalamProses Pembelajaran untukPeningkatan Minat Belajar Siswa padaMata Pelajaran Pendidikan AgamaIslam di Sekolah Dasar Negeri 147Palembang” sebagai bahan kajian. $^{7}$

\section{METODE PENELITIAN}

Jenis penelitian ini adalah penelitian lapangan yang bersifat deskriftif yaitu penelitian yang mengungkapkan fakta yang ada di lapangan dengan observasi danwawancara serta

\footnotetext{
${ }^{6}$ Asmaroni. 2011. "Strategi Guru dalam Mengembangkan Aktivitas Belajar Siswa pada Pembelajaran Pendidikan Agama Islam (PAI) di SDN I Labuhan Dalam Kota Bandar Lampung". Tesis Tidak dipublikasikan. IAIN Raden Fatah, Palembang.

${ }^{7}$ Ibid.
} 
menggunakan data kepustakaan. Jenis penelitian ini bertujuan untuk menggambarkan dan mengungkap, dan menjelaskan. ${ }^{8}$

\section{Sumber Data}

Data penelitian ini bersumber dari data primer dan skunder. Data primer dalam penelitian ini adalah hasil wawancara dan observasi dan angket. Data wawancara bersumber dari kepala sekolah, dan guru, mengenai strategi yang dilakukan guru untuk meningkatkan minat belajar siswa. Data observasi bersumber dari kegiatan yang dilakukan guru PAI pada saat berlangsungnya proses pembelajaran dikelas, sedangkan angket, disebarkan kepada siswa untuk menyaring data tentang tanggapan siswa mengenai strategi guru dan minat belajar siswa. Data sekunder merupakan hasil pengumpulan data dari dokumen sekolahnya. Data dokumentasi yang dikumpulkan terdiri dari struktur organisasi , (profil) sekolah, buku inventaris sekolah, daftar hadir gurudan siswa, silabus, dan RPP. Dalam penelitian ini subjek penelitian adalah kepala sekolah, tiga orang guru PAIdan 30 orang siswa kelas V SD Negeri 147 Palembang tahun pelajaran 2012/2013.

\section{Tennik Pengumpulan Data}

Pengumpulan data adalah cara cara yang digunakan penulis untuk mendapatkan kebenaran yang terjadi pada subjek penelitian atau sumberdata. Adapun beberapa metode yang digunakan dalam pengumpulan data ini yaitu: wawancara, observasi, angket dan dokumentasi.

\section{Teknik Pengolahan dan Analisis Data}

Data yang terkumpul dalam penelitian ini berupa data kualitatif. Dalam menganalisa data kualitatif, penulis menggunakan metode deskriptif analitik yaitu metode yang digunakan terhadap suatu data yang telah terkumpul, kemudian disusun, dijelaskan dan dianalisis kemudian ditarik kesimpulan. ${ }^{9}$ Dalam metode ini ada empat tahapan analisis data yaitu:

a. Pengumpulan data, yaitu proses mengumpulkan semua data dari lapangan penelitian yang diperlukan. Dalam pengumpulan data dilaksanakan kegiatan

\footnotetext{
${ }^{8}$ Arikunto, Suharsimi. 2010. Prosedur Penelitian Suatu Pendekatan Praktek. Renika Cipta, Jakarta.

${ }^{9}$ Surakhmad, Winarno. 2009. Pengantar Penelitian Ilmiah Dasar Metode Teknik. Tarsito, Bandung.
} 
triangulasi, yaitu teknik pemeriksaan keabsahan data yang memanfaatkan sumber lain di luar data sebagai pembanding terhadap data tersebut. ${ }^{10}$

b. Mengklasifikasikan data, yaitu dengan cara menggolongkan sesuai dengan permasalahan yang diteliti.

c. Menjelaskan data angket, keterangan yang telah dihimpun dalam penelitian dan, kemudian dijelaskan arti dan makna yang erkandung pada data tersebut. Dalam proses ini menggunakan dua tahap, yaitu: tahap diskusi dantahap interpretasi.. ${ }^{11}$

d. Menarik Kesimpulan. Berdasarkan data yang sudah didiskusikan dan interpretasikan terhadap data tersebut. Pada akhirnya penulis berusaha menarik kesimpulan. Kesimpulan yang dikemukakan berdasarkan hasil diskusi dan interpretasi terhadap data yang telah dihimpun dalam penelitian. Kesimpulan adalah jawaban jawaban terhadap masalah penelitian yang sudah dirumuskan dalam rencana penelitian. ${ }^{12}$

\section{Landasan Teori}

Secara bahasa "strategi" adalah ilmu siasat, tipu muslihat yang digunakan untuk mencapai maksud. ${ }^{13}$ Secara istilah strategi dapat diartikan sebagai garis besar haluan bertindak untuk mencapai sasaran yang telah ditetapkan. Pada awalnya strategi sebenarnya berasal dari istilah kemiliteran, yaitu usaha untuk mendapatkan posisi yang menguntungkan dan tujuan mencapai kemenangan atau kesukaan. Pembelajaran adalah upaya pendidik untuk membantu peserta didik untuk belajar. ${ }^{14}$

\section{Minat Belajar}

Minat merupakan faktor penentu keberhasilan siswa dalam belajar. Minat merupakan suatu keadaand imana seseorang mempunyai perhatian terhadap suatu objek yang sesuai dengan keinginan untukmengetahui dan mempelajari maupun membuktikan lebih lanjut tentang objek

\footnotetext{
${ }^{10}$ Abdurrahman, Dudung. 2008. Pengantar Metode Penelitian. Kurnia Kalam Semesta, Yogyakarta.

${ }^{11}$ Badudu, J.S. dan Sutan M. Zain. 1994. Kamus Umum Bahasa Indonesia. Pustaka Sinar Harapan, Jakarta.

${ }^{12}$ Sudjana. 2010. Strategi PembelajaranLuar Sekolah. Falah Production, Bandung.

${ }^{13}$ Walgito, Bimo. 2007. Psikologi Umum. Fak. Psikologi UGM, Yogyakarta.

${ }^{14}$ Sanjaya, Wina. 2011. Strategi Pembelajaran: Berorientasi Stándar Proses Pendidikan. Kencana, Jakarta.
} 
tertentu dengan adanya kecenderungan untuk berhubungan lebih aktif terhadap objek tersebut. ${ }^{15}$ Minat adalah aspek yang dapat menentukan motivasi seseorang melakukan aktifitas tertentu. "Minat adalah penerimaan sesuatu di luar dirinya sendiri, makin dekat hubungan tersebut makin besar minatnya untuk mencapai sesuatu". ${ }^{16 ، M i n a t ~(i n t e r e s t) ~ a d a l a h ~ k e c e n d e r u n g a n ~ s e s e o r a n g ~}$ untuk melakukan sesuatu perbuatan. Misalnya minat untuk mempelajari atau melakukan sesuatu." Interest ispersisting tendency to pay attention toand enjoy some activity or content. "Minat pada dasarnya adalah penerimaan akan suatu hubungan antara diri sendiri dengan sesuatu diluar diri. ${ }^{17}$

Berdasarkan beberapa pengertian di atas dapat disimpulkan bahwa minat ialah kecenderungan untuk melakukan sesuatu aktivitas sebagai dorongan untuk mencapai suatu tujuan. Minat muncul karena adanya daya tarik tertentu. Belajar adalah proses bagisiswa dalam membangun gagasan atau pemahaman sendiri, maka kegiatan belajar mengajar hendaknya memberikan kesempatan kepada siswa untuk melakukan hal itu secara lancardan termotivasi.

\section{Faktor-Faktor yang dapat Membangkitkan Minat Belajar}

Berikut ini penulis diuraikan secara rinci bagaimana membangkitkan minat anak dalam belajar.

\section{a. Perhatian}

Perhatian adalah "kegiatan yang dilakukan seseorang dalam hubungan dengan pemilihan rangsangan yang datang dari lingkungannya." Perhatian seseorang tertuju atau terarah pada hal hal yang baru, hal-hal yang berlawanan dengan pengalaman yang baru saja diperolehnya atau dengan pengalaman yang didapat selama hidupnya. Dalam pelajaran, seorang guru dapat berusaha menarik perhatian siswa tentang kata kata penting dalam suatu bacaan dengan memberi warna merah pada kata-kata itu atau dengan member garis di bawah kata-kata tersebut.

\footnotetext{
${ }^{15}$ Mulyasa, E. 2008. Kurikulum Berbasis Kompetensi: Konsep, Karakteristik, dan Implementasi.Remaja Rosdakarya, Jakarta.

${ }^{16}$ Slameto. 2010. Belajar dan Faktorfaktoryang Mempengaruhinya. Rineka Cipta, Jakarta.

${ }^{17}$ Jalaluddin, H. 1997. Psikologi Agama. PT Raja Grafindo Persada, Jakarta.
} 


\section{b. Insentif}

Insentif ialah memotivasi (merangsang) guru dengan memberikan hadiah (imbalan) kepada mereka yang berprestasi di atas prestasi standar. Dengan demikian semangat kerja guru akan meningkat sebab pada umumnya manusia akan senang menerima yang baik-baik saja. Setiap tindakan seseorang merupakan perwujudan dorongannya sebagian besar sangat tergantung kepada rangsangan yang datang dari luar dan persepsinya atas rangsangan tersebut. Insentif merupakan alat yang dapat dipakai untuk membujuk seseorang agar mau melakukan sesuatu yang tidak mau dilakukan/yang tidak dilakukan dengan baik. Insentif dapat berbentuk pemberian hadiah: berupa benda, barang, atau uang.

\section{c. Pembelajaran Pendidikan AgamaIslam (PAI)}

Definisi Pendidikan Agama Islam (PAI) disebutkan dalam Kurikulum 2004 Standar Kompetensi Mata Pelajaran Pendidikan Agama Islam SD dan MI adalah "Pendidikan Agama Islam adalah upaya sadar dan terencana dalam menyaipkan peserta didik untuk mengenal, memahami, menghayati, bertakwa, berakhlak mulia, mengamalkan ajaran agama Islam dari sumber utamanya kitab suci Al-Qurandan Hadis melalui kegiatan bimbingan pengajaran, latihan, serta penggunaan pengalaman.”. 18

Pendidikan Agama Islam adalah usaha sadar untuk menyiapkan siswa agar memahami ajaran Islam (knowing), terampil melakukan atau mempraktikkan ajaran Islam (doing), dan mengamalkan ajaran Islam dalam kehidupan sehari-hari (being). Berdasarkan batasan di atas, penulis dapat menyimpulkan bahwa pendidikan Islam adalah suatu system yang memungkinkan seseorang (peserta didik) agar dapat mengarahkan kehidupannya sesuai dengan ideologis atau cara pandang umat Islam selama hidup di dunia. ${ }^{19}$

\section{HASIL PENELITIAN}

Berdasarkan data angket diketahui bahwa responden yang menjawab a rata-rata27,33\%, responden menjawab b rata-rata sebesar 36,17\%, responden menjawab c rata-rata sebesar $26 \%$, responden menjawab d rata-ratasebesar 10,50\%. Dengan demikian dapat disimpulkan bahwa

\footnotetext{
${ }^{18}$ Moleong, Lexy J. 2010. MetodologiPenelitian Kualitatif. Edisi Revisi. Remaja Rosdakarya, Bandung.

${ }^{19}$ Tafsir, Ahmad. 2007. Ilmu Pendidikan dalam Persepektif Islam.Remadja Rosdakarya, Bandung.
} 
strategi guru dalam meningkatkan minat belajar siswa pada mata pelajaran PAI dalam kategori baik.

Hasil wawancara dengan kepala SD Negeri 147 Palembang diketahui minat belajar siswa cukup besar. Menurut beliau, Minat belajar siswa cukup besar, terbukti dari kehadiran pada absen, keseriusan dalam kelas, kepatuhannya terhadap gurunya misalnya dalam hal hafalan, PR, tugas, dan lain-lain selalu dikerjakan dengan baik (Hasil wawancara tanggal 8 Juni2013). Pendapat di atas merupakan data pendukung hasil penelitian yang menyatakan bahwa minat belajar siswa pada mata pelajaran PAI cukup besar. Siswa aktif belajar, mengikuti kegiatan pembelajaran di kelas, mengerjakan tugas, dan latihan yang diberikan oleh guru PAI.

\section{Strategi Pembelajaran Guru PAI SDN 147 Palembang}

Strategi merupakan unsure penting guna mencapai tujuan pembelajaran yang telah ditetapkan. Berdasarkan hasil wawancara dengan guru PAI SDN 147 Palembang. Beliau mengatakan bahwa pelaksanaan strategi pembelajaran mengacu pada tujuan pendidikan umum sebagaimana tercantum dalam UU Sisdiknas No. 20Tahun 2003, yaitu agar siswa secara aktif mampu mengembangkan potensi dirinya untuk memiliki kekuatan spiritual keagamaan, pengendalian diri, kepribadian, kecerdasan, akhlak mulia, serta ketampilan yang diperlukan dirinya, masyarakat, bangsa dan negara. Selain itu, mengacu pada tujuan institusional yang tertuang dalam visi, misi SDN 147 Palembang, menurut guru PAI SD Negeri 147 Palembang bahwa proses pembelajaran PAI dilaksanakan sesuai dengan kurikulum yang bertujuan untuk membentuk pribadi muslim yang bertaqwa kepada Allah SWT dan berakhlak mulia (Hasil wawancara dengan guru PAI SD Negeri 147 Palembang tanggal 24 Mei 2013).

Hasil wawancara dengan guru PAI tanggal 22 Mei 2013, dan dikuatkan dengan hasil observasi, diperoleh data bahwa metode pembelajaran yang diimplementasikan guru dalam proses pembelajaran PAI sebagai berikut: (1) ceramah; (2)diskusi; (3) drill/latihan; (4) penugasan;(5) demonstrasi.Untuk membangkitkan minatbelajar siswa pada mata pelajaran PAI, guru melakukan strategi yaitu dengan memberikan perhatian dan insentif. Peneliti mengumpulkan data ini dari hasil observasi terhadap guru mata pelajaran PAI yang sedang mengajar dikelas.

Berdasarkan data tersebut diketahui bahwa responden 1 memperoleh rata-rata 71,43\%, responden 2 memperoleh rata-rata78,57\%, dan responden 3 memperoleh rata-rata 85,71\%. Rata- 
rata aktivitas guru mencapai 78,57\%. Adapun strategi guru untuk meningkatkan minat belajar siswa pada mata pelajaran Pendidikan Agama Islam di SDN 147 Palembang ditinjau dari perhatian dan insentif dapat dijelaskan sebagai berikut. Dari data tersebut dapat disimpulkan bahwa guru memberikan perhatian kepada siswa dilakukan sebesar 80,90\%. Dari data tersebut dapat disimpulkan bahwa guru memberikan insentif kepada siswa dilakukan sebesar76,19. Dalam setiap upaya yang dilakukan untuk menjadi lebih baik, tentunya juga tidak terlepas dari beberapa faktor. Adapun faktor-faktor tersebut sebagai berikut (Hasil Wawancara dengan guru PAI, tangga 14 Juni 2013):

\section{Faktor Pendukung}

a. Adanya koordinasi yang baik dengan kepala sekolah, guru kelas dan guru PAI untuk mengikuti pelatihan, training, lokakarya dan workshop pendidikan yang diadakan baik disekolah maupun di luar sekolah

b. Lokasi yang cukup tenang, jauh dari keramaian sehingga dapat membantu siswa belajar dengan tenang.

2. Faktor Penghambat

a. Kurangnya partisipasi orang tuadalam memantau belajar siswasaat di rumah.

b. Kurangnya fasilitas yangmemadai. seperti: buku pegangansiswa yang masih sangat terbatasdan alat peraga atau mediapembelajaran yang mendukungproses pembelajaran.

\section{KESIMPULAN}

Setelah diadakan penelitian tentang strategi pembelajaran PAI dalam peningkakan minat belajar siswa kelas V di SDN 147 Palembang, dapat ditarik kesimpulan sebagai berikut: Minat belajar siswa kelas $\mathrm{V}$ pada mata pelajaran PAI tergolong baik. Hal ini disebabkan karena beberapa faktor yang telah mendukung minat belajarnya, yaitu dari faktor perhatian dan insentif. Minat belajar Pengembangan strategi pembelajaran untuk meningkatkan minat belajar siswa kelas $\mathrm{V}$ yang dilakukan guru sudah bervariasi, walaupun pelaksanaannya masih terdapat beberapa kekurangan. Beberapa kekurangan tersebut yaitu: prosedur yang digunakan guru belum sesuai dengan prosedur strategi pembelajaran yang seharusnya dan guru juga selalu menggunakan metode ceramah setiap mengawali proses pembelajaran, sehingga hasil 
pembelajaran yang diperoleh siswa belum maksimal. Hal ini dapat dilihat dari hasil ulangan dan remedial siswa yang kurang memuaskan.

\section{DAFTAR PUSTAKA}

Abdurrahman, Dudung. 2008. Pengantar Metode Penelitian. Kurnia Kalam Semesta, Yogyakarta.

Arikunto, Suharsimi. 2010. ProsedurPenelitian Suatu Pendekatan Praktek. Renika Cipta, Jakarta.

Asmaroni. 2011. "Strategi Guru dalam Mengembangkan Aktivitas Belajar Siswa pada Pembelajaran Pendidikan Agama Islam (PAI)di SDN I Labuhan Dalam Kota Bandar Lampung". Tesis Tidak dipublikasikan. IAIN Raden Fatah, Palembang.

Badudu, J.S. dan Sutan M. Zain. 1994.Kamus Umum Bahasa Indonesia. Pustaka Sinar Harapan, Jakarta. Dalyono, M. 2010. Psikologi Pendidikan. Rineka Cipta, Jakarta.

Departemen Pendidikan dan Kebudayaan. 007. Pelaksanaan Proses Belajar Mengajar. Balai Pustaka, Jakarta.

Depdiknas. 2006. Kurikulum Pendidikan Dasar. Jakarta.

Djamarah, Syaiful Bahri dan Aswan Zain. 2010. Strategi Belajar Mengajar. Rineka Cipta, Jakarta.

Hamalik, Oemar. 2010. Pendidikan Guru: Berdasarkan Pendekatan Kompetensi. Bumi Aksara, Jakarta.

Jalaluddin, H. 1997. Psikologi Agama. PT Raja Grafindo Persada, Jakarta.

Moleong, Lexy J. 2010. Metodologi Penelitian Kualitatif. Edisi Revisi. Remaja Rosdakarya, Bandung.

Mulyasa, E. 2008. Kurikulum Berbasis Kompetensi: Konsep, Karakteristik, dan Implementasi. Remaja Rosdakarya, Jakarta.

Nurdin, Muslim, dkk. 2002. Moral dan Kognisi Islam. Alfabeta, Bandung.

Purwanto, Ngalim. 2008. Psikologi Pendidikan. Rineka Cipta, Jakarta.

Sanjaya, Wina. 2011. Strategi Pembelajaran: Berorientasi Stándar Proses Pendidikan. Kencana, Jakarta. 
Slameto. 2010. Belajar dan Faktor factor yang Mempengaruhinya. Rineka Cipta, Jakarta.

Sudjana. 2010. Strategi Pembelajaran Luar Sekolah. Falah Production, Bandung.

Surakhmad, Winarno. 2009. Pengantar Penelitian Ilmiah Dasar Metode Teknik. Tarsito, Bandung.

Tafsir, Ahmad. 2007. Ilmu Pendidikandalam Persepektif Islam. Remadja Rosdakarya, Bandung.

Walgito, Bimo. 2007. Psikologi Umum. Fak. Psikologi UGM, Yogyakarta.

Zamroni. 2010. Pendidikan Masa Depan. Bigraf Publising, Yogyakarta. 